\title{
Merger Momentum and Market Valuations: The UK Evidence
}

\author{
Antonios Antoniou, Jie (Michael) Guo and Dimitris Petmezas* \\ Centre for Empirical Research in Finance \\ Durham Business School \\ University of Durham
}

UK

\begin{abstract}
This study examines the effect of merger momentum on acquirer's returns both in the shortand long-run. The focus is on high-valuation markets and the source of momentum is investigated employing three different hypotheses: the neoclassical hypothesis, the hubris hypothesis and the investor sentiment theory. The neoclassical theory predicts increase in value with no long term reversals and hubris hypothesis suggests destruction of value in both short and long-run due to managerial overconfidence. However, our results support the investor sentiment (optimism) hypothesis since investors are found to earn significant gains in the shortrun but returns are reversed in the long-run as initial expectations may not be fully met when combined firms' accomplishments become known over time. The results are robust after controlling for several acquirer and deal characteristics.
\end{abstract}

JEL Classification: G14; G34.

Keywords: Mergers \& Acquisitions, Market Valuations, Merger Momentum, Short and Longterm wealth effects

${ }^{*}$ Corresponding author, Department of Economics and Finance, Durham Business School, University of Durham, DH1 3LB, Durham, U.K. Tel: (0191) 334-5451, Fax: (0191) 334-5201, E-mail: jie.guo@dur.ac.uk 


\section{Introduction}

A sizeable stream of theoretical and empirical research on the motivation for and profitability of mergers \& acquisitions (M\&As) has recently focused on merger momentum providing some new insights into various merger theories. It has been established that merger activity comes in waves, ${ }^{1}$ and that announcement returns are significantly positive for target shareholders while the returns to bidder shareholders' vary depending on, among others, the method of payment, the bidder's size and book-to-market, and the type of target. ${ }^{2}$ Moreover, recent studies have shown that the market's reaction to a merger is positively correlated with the response to other mergers in the recent past (Rosen 2006). Empirical evidence regarding post-acquisition returns to acquiring firms' shareholders demonstrates that cash payments systematically outperform stock payments (Loughran and Vijh 1997), value acquirers outperform glamour acquirers (Rau and Vermaelen 1998), and small acquirers show, in general, better performance than large acquirers (Moeller, Schlingemann, and Stulz 2005). ${ }^{3}$

Researchers have recently begun to explore the possible link between M\&A activity and stock prices. Jovanovic and Roussean (2002) showed that period of high merger activity are correlated with high market valuations. Rhodes-Kropf and Viswananthan (2004) developed a theoretical model in which both firm-specific and market-wide misevaluation appears to cause merger waves. Shleifer and Vishny (2004) also suggested a model showing the impact of market valuations on the decision to acquire, the method of payment used, the performance of acquirers, and the occurrence of merger waves. Rosen (2006) defined a new area of merger momentum and found a positive correlation between the market reaction to a merger announcement and recent market conditions. ${ }^{4}$ The present study differs from Rosen's (2006) in two main contexts: first, an investigation is made into whether merger momentum exists and, if

\footnotetext{
${ }^{1}$ See Andrade, Mitchell, and Stafford (2001), Holmstrom and Kaplan (2001), and Rosen (2006).

${ }^{2}$ See Travlos (1987), Moeller, Schlingemann, and Stulz (2006), Rau and Vermaelen (1998), and Fuller, Netter, and Stegemoller (2002).

${ }^{3}$ In the literature the concept 'merger' differs from the concept 'acquisition', since the first is usually described as representing a 'friendly' union of two firms of roughly equal size, while the latter implies the more hostile character of a takeover. Note, however, that the terms 'merger' and 'acquisition' are used interchangeably in this discussion.

${ }^{4}$ Rosen (2006) suggests that the bidder's stock price is more likely to increase when a merger is announced if and when recent mergers by other firms have been received well or if the overall stock market is doing better. According to the author this is evidence of merger momentum which however is followed by long-term reversals.
} 
it does, what its influence is on acquiring firms' returns during high-valuation periods. The market index $\mathrm{P} / \mathrm{E}$ ratio was used as a proxy for market valuations, in the same way that investors use a firm's P/E ratio to measure over- or under- valuation. Second, a UK sample was used, whereas Rosen's analysis is based on US data. The findings of the present study are consistent with Rosen's arguments, confirming that the effect of investor optimism on acquirer performance is not a US phenomenon.

There are three main theories that are all in line with the notion of merger momentum, although each gives different predictions regarding bidders' returns. First, the neoclassical theory of mergers assumes that managers act to maximize shareholder value. The notion here is that the merger is a value-improving response to various industry shocks, such as antitrust policy or deregulation (Mitchell and Mulherin 1996, and Jovanovic and Rousseau, 2002). According to this theory, merger momentum may result from shocks that increase the synergies for a group of mergers. Mergers announced following these shocks should be better on average than other mergers in both the short-run and long-run, and merger momentum might result from the correlated announcement returns leading from these industry shocks.

The second theory is the hubris hypothesis (Roll, 1986) of mergers which assumes that managers are overconfident that they can increase firm's value and over-invest. According to this theory, merger momentum may result from a group of managers being afflicted with overconfidence when they have sufficient external resources to finance a merger. The managers thus want to make acquisitions even when they anticipate the announcement will generate a decline in stock prices. They expect that they will be proved correct in the long-run. Because shareholders do not have complete control, they cannot prevent managers from making such acquisitions. If it is the case that hubris drives acquisitions, rational shareholders should discount the share price. Since the acquisitions harm firm value, there is no reason the initial stock price reaction should reverse in the long-run. These types of mergers are likely to be more usual during high-valuation periods, simply because boom markets provide more external resources and more takeover opportunities that increase managerial hubris.

Finally, the third theory is that merger momentum occurs in particular periods when over- 
optimism is predominant in the market, i.e. during high-valuation periods. Helwege and Liang (1996) argue that shareholder reaction to a corporate announcement can be affected by investor sentiment, i.e. the reaction of investors to factors other than the value created by the event. ${ }^{5}$ When the merger market is overheating, especially during high-valuation periods, a strong merger momentum will be observed because the investors (and in many cases managers) as a group are more easily infected by over optimism about merger announcements. According to this theory, a long-run stock return reversal should be predicted as the optimism is eventually replaced by reality.

In addition, previous studies have provided evidence that merger deals are more frequent when the overall stock market valuation is high (Shleifer and Vishny 2004, and Dong, Hirshleifer, Richardson, and Teoh 2006). Bidders prefer to take advantage of their overvalued shares when their stock price becomes substantially high; the biggest capital expenditure at those times will be the taking over of a relatively less overvalued firm by issuing stock at an overvalued price. Alternatively, when a firm's stock price becomes overvalued, any attempt to eliminate it will be viewed un-favorably by the capital markets, and managers may risk their careers. Hence, it is likely that they will engage in takeovers and further boost the prices for the purposes of earnings management (Jensen, 2004). The consequential overall stock market overvaluation could result in merger momentum; the findings of the present research are in line with this argument.

In this study, two fundamental questions are addressed, assuming that market valuations do impact on acquisition decisions, and mergers do come in waves: Does this impact on acquisitions have consequences for the market's reaction to merger deals? Do these reactions rely on merger deals in the recent past during hot merger waves?

We use the returns to UK bidding firms over different market valuation periods as an indicator of merger quality, in order to shed light on the different theories of when and why acquisitions occur in conditions of market-wide high-valuation periods. Thus, we investigate whether market-wide high valuation periods influence reactions to merger announcements. This

\footnotetext{
${ }^{5}$ Helwege and Liang (1996) found evidence of overoptimism in hot IPOs markets.
} 
study contributes to the literature in several ways. First, our results indicate that corporate acquisitions' performance is an integral component of market wide (mis)valuations. Second, the results support the predictions of overoptimistic investors' beliefs. We find that the market reaction to a merger announcement is positively correlated with the response to other mergers in the recent past, especially during a high market valuation period while acquirers experience significantly long-run reversals for deals announced in hot merger markets. Third, firms that announce merger deals during hot merger markets perform significantly less well than mergers announced during other periods. These findings also suggest that managerial motivation may influence merger decisions in hot merger markets. Finally, the results are not sensitive to various acquirer and deal characteristics.

The rest of the paper is organized as follows: Section 2 classifies the markets into high-, neutral- and low-valuation periods and describes the data, model development and methodologies. Section 3 presents and interprets the empirical results. Section 4 concludes the paper.

\section{Data and Methodology}

\subsection{Classification of High- and Low-Valuation Markets}

Each calendar month was classified as a high-, neutral-, or low-valuation month on the basis of the P/E ratio of the value-weighted market index (TOTMKUK). ${ }^{6}$ In order to classify each month into a valuation group it was first necessary to de-trend the market (TOTMKUK) $\mathrm{P} / \mathrm{E}$ by removing the best straight line fit (OLS) from the P/E of the month in question and the five preceding years. ${ }^{7}$ The month in question was classified into an above (below) average group if its de-trended index P/E was above (below) the past five-year average. Then the

\footnotetext{
${ }^{6}$ The P/E data was collected from the Thomson Financial Datastream. Since Datastream provides data for the P/E ratio of the FTSE All Share Index from 1993 onwards, the TOTMKUK (Total Market UK) was used, which is the closest index to the FTSE All Share (the correlation between these two indices is 99.92\%). Jovanovic and Rousseau (2002) found that merger waves coincide with periods of high priceearnings ratios on the stock markets, which is used as a proxy of market valuations. In an independent US study, Bouwman, Fuller, and Nain (2005) also employed the P/E ratio of the market index (S\&P 500).

${ }^{7}$ It is necessary to remove the trend from the market P/E ratio because P/E ratios have trended upwards. Hence, not removing the trend would result in a systematic classification of more recent acquisitions as high-valuation acquisitions and older acquisitions as low-valuation acquisitions. The results are robust to reasonable changes in the length of the historical data used in the detrending approach.
} 
months were ranked in order of the de-trended P/E. Months that belonged to the top half of the above average group were classified as high-valuation months and those that belonged to the bottom half of the below average group were classified as low-valuation months. All remaining months were classified as neutral-valuation months.

\subsection{Selection Criteria and Sample Description}

The sample under examination comprised 1957 domestic acquisitions undertaken by UK firms between January $1^{\text {st }}, 1985$ and December $31^{\text {st }}, 2002$, as provided by the SDC database. For the purposes of this work, we require that the acquirer purchases at least $50 \%$ of target's shares and after the purchase the bidder owns at least $90 \%$ of the target. Acquisitions were included in the sample if the following conditions were met:

1. The acquirer was a UK firm listed on the London Stock Exchange.

2. The target was a public, private or subsidiary UK firm.

3. If daily acquirer return data was available for two days before the announcement date until two days after the announcement date, and if the following acquirer data was available for the three years following the acquisition: market equity (from June each year), the B/M ratio (from December each year) and monthly return data.

4. The transaction value was 1 million pounds or more to avoid results being generated by very small deals. ${ }^{8}$

5. The deal value represented at least $5 \%$ of the market value of the acquirer. The market value was measured as the monthly share price multiplied by the number of ordinary outstanding shares one month before the announcement date.

6. Both bidding and target firms were non-financial and non-utility firms (following Fama and French 1992). ${ }^{9}$

7. Finally, outliers were eliminated. Any firm with a negative book value of equity or with a ratio of the $\mathrm{B} / \mathrm{M}$ value of equity of over 10 was dropped. Firms with returns on assets of

\footnotetext{
${ }^{8}$ We also employed a 0.5 million and 2 million pounds cut-off points respectively and the results (not reported for brevity but available upon request) remain qualitatively similar.

${ }^{9}$ Fama and French (1992) suggest that the leverage levels of financial firms differ qualitatively from those of non-financial firms when used as an indicator of financial distress.
} 
below $100 \%$ or above $200 \%$ were also excluded. Once this was done, the mergers in the top $1 \%$ and the bottom $1 \%$ of the abnormal announcement returns were also dropped.

In addition to these requirements, clustered acquisitions, where an acquirer announced two or more acquisitions within five days, were also excluded from the analysis in order to isolate the overlapping effect among deals on bidder returns. The sample was then divided into three subsets based on the method of payment for the acquisition, i.e. pure cash, pure stock, and mixed. Cash acquisitions include transactions made solely in cash, or cash and debt. Stock acquisitions are defined as transactions made solely in common stock. Mixed payment acquisitions consist of all acquisitions in which the payment method is neither pure cash nor pure stock, and methods classified as "other" by SDC.

Table 1 shows that there are some distinctive trends in the sample. First of all, cash was used to finance $55.9 \%$ of the deals, while only $6.9 \%$ of deals used stock as the method of payment, which is consistent with the findings of previous studies based on the UK takeover market. ${ }^{10}$ Secondly, a clear increasing trend in merger activity can be observed as time passes. This trend reaches a peak in 2000 (178 deals), while the number of mergers at the end of the 1980s was similar to that of the 1990s, indicating that a strong merger wave took place at the end of each decade. However, the transaction values indicate that the merger wave of the late 1990s was on a much larger scale than that of the late 1980s.

[Insert Table 1 About Here]

\subsection{Model Development}

The empirical model developed in this study tests how recent merger activity and changes in stock prices affect the market reaction to a merger announcement in both the short- and long-run. ${ }^{11}$ Furthermore, we specifically focus on deals made in high-valuation periods and subdivide the sample using a market valuation approach to shed light on different market predictions regarding merger momentum based on different market conditions. The sample has

\footnotetext{
${ }_{11}^{10}$ See Faccio and Masulis (2005) and Doukas and Petmezas (2007).

${ }^{11}$ This model was first advocated by Rosen (2006).
} 
been partitioned into hot and cold market periods according to the level of transaction intensity in the merger market. Thus, the total transaction values have been used along with merger numbers as proxy for hot and cold markets. In this study, the focus is on bidding firms only. Hence, deals involving private and subsidiary targets have been included. In order to test market reaction as accurately as possible, the pre-takeover financial status (value versus glamour) ${ }^{12}$ of the bidder and the specific conditions of the acquisition have been controlled for. The model applied is the following while Table 2 presents the descriptive statistics for all the right-hand side variables of our empirical model:

Market Reaction $=F($ Merger Momentum, Market Momentum, Bidder-Specific Merger Momentum, Bidder-Specific Stock Momentum, Deal-Specific Control Variables)

Market reaction is a function of the following variables: 1) The trailing 12-month average CAAR, which is the average CAAR for all sample mergers ending 3 days before an announcement. The mean value is $1.2 \%$, which suggests that bidder gain positive announcement return through out the sample; 2) the trailing 12-month number of mergers. These 2 variables are the ones used to proxy for merger momentum; 3) the trailing 12-month return on FTSE All-Share Index, that is the return on the FTSE all share index in the year ending three days before a merger announcement and it has a mean value of $13.9 \%$. This is the proxy for market momentum; 4) bidder specific merger momentum variable is a dummy that takes the value of one if this is the first announcement by the bidder over the prior 3 years and zero otherwise. The mean value is $59.4 \%$; 5) bidder specific stock momentum variable represents the number of mergers by the bidder over the 3-year period prior to the announcement, and the mean value equals to $0.71 \%$. We also use other variables: whether stock or other means of financing are used as a method of payment, whether target is public, private or subsidiary firm, the acquirer's market value in million pounds, the acquirer's book-tomarket ratio, the relative size of target to bidder, and whether the merger was diversifying. Public acquisitions represent only $2.2 \%$ of our sample, which suggest that private and

\footnotetext{
${ }^{12}$ Rau and Vermalen (1998) found that the long-run underperformance of acquiring firms in mergers is predominantly caused by the poor post-acquisition performance of the low B/M 'glamour' firms. They interpreted this finding as evidence that both market and management over-extrapolate the bidder's past performance when they assess the desirability of an acquisition.
} 
subsidiary acquisitions are the major components of the UK merger activity. Acquirer's book-tomarket value is on average 0.47 while diversifying acquisitions stand for the $40.3 \%$ of our sample.

[Insert Table 2 About Here]

\subsection{Methodology}

For the short-run analysis, the study follows Fuller et al. (2002), and Dong et al.'s (2006) standard event study methodology and calculates Cumulative Abnormal Returns (CARs) for the five-day $(-2,+2)$ period around the takeover announcement. ${ }^{13}$ More specifically, the abnormal returns were estimated by using a modified market-adjusted model:

$$
A R_{i t}=R_{i t}-R_{m t}
$$

where $R_{i t}$ is the return on firm $i$ and $R_{m t}$ is the value-weighted market index return. ${ }^{14}$ This approach amounts to assuming that $\alpha=0$ and $\beta=1$ for the firms in the sample.

For the long-run analysis the BHAR methodology was used. Barber and Lyon (1997) advocated the use of BHARs where the sample firms are matched to control firms of similar size and B/M ratios. They found that this approach yielded well-specified test statistics as it avoids the rebalancing, skewness, and new listing bias problems that other techniques suffer from. Although CARs overcome event-clustering problems, they are subject to the measurement, new listing, and skewness biases described by Barber and Lyon (1997). Another problem with CARs is that they are poor in detecting any long-run abnormal performance. Moreover, as compared to CARs, BHARs are superior in measuring the returns to an investor who holds a security for a long post-event period. In addition, corporate events such as M\&As have been documented as occurring in waves, and the calendar-time portfolio approach will understate the extent of abnormal returns since it smoothes such returns over the hot and cold

\footnotetext{
${ }^{13}$ Since about $30 \%$ of the acquiring firms in the sample engaged in frequent acquisitions within 200 days, previous announcements were included in the estimation period rendering market parameter estimations to an extent biased. Additionally, it has been shown that for short window event studies, weighting the market return by the firm's beta does not significantly improve estimation (Brown and Warner 1980). However, CARs were also calculated following Brown and Warner's (1985) standard event study methodology and these yielded qualitatively similar results that are not reported here for reasons of brevity. ${ }^{14}$ The results hold even when using the indices of different industries.
} 
periods. ${ }^{15}$ The BHAR is here defined as the value of holding a long position in the stock of the bidding firm and a short position in a benchmark index over the time horizon (including periods before and after the merger is completed):

$$
B H A R=\prod_{t=1}^{T}\left(1+R_{t}\right)-\prod_{t=1}^{T}\left(1+R_{\text {index }, t}\right)
$$

As discussed above, one benchmark (the market index) was used, but the results are generally similar when using an industry-based index. Two time horizons were examined, one that included the announcement period and one that focused on the post-announcement period only. The first, which is referred to as the total window, runs from two days prior to a merger announcement to three years after the announcement, while the second starts three days after the announcement day and ends three years after. The total window captures the total stock market impact of the merger, including the effect of the announcement. Only mergers for which there was post-announcement data for at least one year were included.

\section{Empirical Results}

\subsection{The Short-Run CAR regression results}

Table 3 presents the results for the short-run CAR regressions carried out on the merger momentum variables, which were proxied by the twelve-month trailing average CARs and twelve-month number of mergers. These regressions include controls for the form of financing, the type of targets, firm-specific financing characteristics, a dummy for whether a merger was diversifying. The full sample regression indicates that there is evidence of merger momentum at the overall market-level but not at the firm-level. The market-wide merger momentum variable, which is the coefficient for the trailing twelve-month average CAR, is positive (0.20) and statistically significant at the $1 \%$ significance level. However, the coefficient of the trailing twelve-month number of mergers (which captures merger waves) is insignificant. Consistent with Rosen (2006), this may be due to the fact that there were two merger waves over the whole sample period (1988 to 1989 and 1997 to 2000), with the latter being much greater in

\footnotetext{
${ }^{15}$ CTPRs were also used to examine the long-run returns and produced qualitatively similar results that are not reported here for reasons of brevity.
} 
terms of both quantity and value and dominating the effect of the first wave.

The regression based on the high-valuation period portfolio indicates that there is a significant positive relationship between merger momentum variables and short-run market reaction. A $1 \%$ increase in trailing 12-month average cumulative abnormal announcement return (CAAR) boosts the bidders' CARs by $0.41 \%$. This result is in line with the hypothesis that merger momentum is more significant during high-valuation markets simply because investor sentiment for acquisitions is stronger during these periods. On the other hand, when assessing merger momentum in neutral and low valuation periods respectively we find a smaller in magnitude and statistically insignificant relationship with bidder's returns.

Table 3, panel B reports the results of the CAR regressions carried out on the market momentum variables that were proxied by the trailing twelve-month returns on the market index. Mergers may also be affected by conditions in the broader stock market. As noted earlier, merger waves generally occur in periods of rising stock prices. To examine whether stock prices were rising, we test the changes in the index during the period starting one year prior to a merger announcement and ending three days before the announcement. The results suggest that the market index is positively (negatively) associated with bidders' announcement returns during high (low)-valuation periods. For every percentage point increase in the market index in the twelve months prior to an announcement made during a high (low)-valuation period it raised (decreased) the CAAR by a significant $0.035 \%(-0.039 \%)$. For the rest of the portfolios, the coefficients are insignificant.

Further, the relationship between the CARs and the bidder-specific merger momentum variables is examined and presented in Table 3 Panel C. The bidder-specific merger momentum was proxied using three variables: first, the quality of a firm's acquisition was measured using the five-day announcement return on the last merger undertaken by the bidding firm, setting the restriction that the announcement occurred in the previous three years. The number of acquisitions announced by the bidder in the previous three-year period was used to measure merger activity. Previous studies have reported that the characteristics 
between frequent and infrequent bidders differ. ${ }^{16}$ Thus, we introduce a dummy which takes the value one when the merger announcement was the first made by the acquirer in the previous three years. A statistically significant positive relationship was found between the bidder's return on the previous announcement and the short-term return on the present one. A $1 \%$ increase in the bidder's previous announcement return caused a $0.045 \%$ increase in the present announcement return for the high-valuation control portfolio. The positive and significant coefficient of 0.008 between the first merger dummy and the bidder's CAR for the highvaluation control portfolio suggests that bidders gain from previous experience during highvaluation periods. Interestingly, during other periods this relationship is insignificant and in some cases negative. Results for the regression carried out on the number of mergers that bidders had made in the previous three years show that the short-run returns of present deals depend on factors other than the firm's merger activity. Thus, it seems that the effect of previous mergers on the short-run reaction to a current merger depends on the market's reaction to the bidder's previous deals, rather than how many mergers were undertaken.

In Panel D, the bidder-specific merger momentum was measured by the bidder-specific returns in the period leading up to the merger announcement using the BHAR for the period starting one year prior to the merger announcement and ending three days before the announcement. The bidder's trailing twelve-month return was negatively related to its CAR on the current merger announcement; where the previous one-year BHAR increased by $1 \%$, the CAR from the announcement decreased by $0.05 \%$. During the high-valuation periods, the magnitude was lower and the results show a more significant relationship.

The robustness of the results was further checked based on other control variables (Panel E). The targets were divided into three groups: public firms, private firms, and subsidiaries, and were further partitioned by the form of acquisition financing: stock acquisition and payment that included at least some other type of financing. The results show that the acquisitions financed with stocks generated, in general for all samples insignificant announcement returns $(-0.18$, $t=-1.55)$. On the other hand, deals financed with cash or other forms of payment experienced

\footnotetext{
${ }^{16}$ See Fuller et al. (2002) and Doukas and Petmezas (2007).
} 
significant positive announcement returns $(0.15, \mathrm{t}=2.32)$. This result is in line with most previous findings. ${ }^{17}$ As Fuller et al. (2002) suggest, public and private targets have significantly different characteristics. Thus, here the public and other targets were examined separately and it was found that for most of the control portfolios, private acquisitions yielded significant positive announcement returns.

Previous studies have found that returns to bidding firms are lower when the merger is diversifying. ${ }^{18}$ To control for this, an acquisition is defined as diversifying when the acquirer's two-digit SIC code is different from that of the target company. A dummy variable was constructed that took the value 1 if a merger was diversifying, that is, if it involved firms from two different industries. In the sample under study, $40.3 \%$ of all mergers are diversifying, which is relatively high compared to other countries. We find that for most of the control portfolios, diversifying mergers have a positive correlation with the announcement returns, although for the high-valuation control portfolio this relationship was insignificant and relatively weak; this is probably due to mergers tending to be concentrated in specific industries during high-valuation periods.

The bidding firms have an average of 105.8 million pounds in assets and a median of 40.2 million pounds in assets. Because of the wide range of bidder size the log of the total assets was included as a control variable. The size is negatively associated to the bidder's short-run return across the sample period and during the early period; this result is consistent with Loderer and Martin (1992). However, bidder's size is positively (negatively) and significantly related to the bidder's short-run return for the high (low)-valuation control portfolio $(0.006$, $\mathrm{t}=1.73$ for high-valuation acquisitions, $-\mathbf{0 . 0 3 7}, \mathrm{t}=-1.74$ for low-valuation acquisitions). This may be due to the fact that larger firms have more access to external financing and greater bargaining power, especially during high market valuation periods when most firms tend to be to a great extent overvalued by the market.

\footnotetext{
${ }^{17}$ See for example, Travlos (1987), Asquith, Bruner and Mullins (1987) and Servaes (1991)

${ }^{18}$ See Morck, Shleifer, and Vishny (1990), Lang and Stulz (1994), Berger and Ofek (1995), Servaes (1996), However, Jensen and Ruback (1983), Bradley, Anand, Desai, and Kim (1988), found that the announcements of diversifying acquisitions were generally associated with small positive abnormal returns.
} 
The ratio of target to bidder size in the sample had a mean of $24.9 \%$ and a median of $14.6 \%$. This ratio was included as a control variable as previous studies reported that it is correlated with bidders' short-run returns. ${ }^{19}$ There is a positive correlation for all the control portfolios, which more pronounced (insignificant) for the high (low)-valuation portfolios.

Finally, the financial strength of the bidding firms was controlled for using the B/M ratio. Lang, Stulz, and Walkling (1989) and Servaes (1991) provided evidence that high book-tomarket ratio is associated with a larger announcement CAR. The B/M ratio was calculated using data available for the year prior to the merger announcement. The average ratio in the sample was 0.47 , and this is significantly positively related to the CAR.

[Insert Table 3 About Here]

\subsection{The Long-run BHAR Regression Results}

The BHAR regression results are presented in Table 4. The same control variables as those used to examine the short-run CAR were used in addition to an independent variable, the CAR, for the post-announcement period. First, the regression results for the BHAR on the CAR and market momentum variables were examined in Panel A. As with the short-run regressions, the trailing twelve-month return on the market index was used as a proxy for market momentum.

Panel A shows that coefficient of the CAR variable was statistically significant, which means the announcement abnormal returns were given back in their entirety during the postannouncement period $(-1.03, \mathrm{t}=-2.76)$. For acquisitions that took place during high (low)valuation periods, the magnitude of the reversion was even higher (lower) and more significant $(-1.08, t=-3.35)$. However, this does not imply that the merger created no synergies, since any benefits accruing to the owners of the target were excluded.

Panel B shows that consistent with the short-run analysis, the market-wide merger momentum was proxied using twelve-month trailing average CARs in the market. Accordingly, to capture merger waves the trailing twelve-month number of mergers was used. The results show that the measure of market-wide merger momentum is negative and significant, both in

\footnotetext{
${ }^{19}$ Rosen (2006) suggests that the relative size of the merging firms affects the magnitude of the synergy. This view is in line with Asquith et al. (1983), Jensen and Ruback (1983), Travlos (1987), Servaes (1991) and Fuller et al. (2002) who show that announcement returns increase with the target's size relative to the bidder.
} 
the post-announcement period and in the total window (as described in section 2.4). Notably, for the high (low)-valuation control portfolios this negative relation is more (less) pronounced. A possible explanation is that deals announced during high (low)-valuation periods are more (less) easily infected by investor optimism. As time passes, the market realizes that its initial expectations were optimistic, thus a more significant long-run reversal is observed.

These results suggest not only that firms announcing deals in a hot merger market have a downward drift in their stock price in the post-announcement period, but that the deals announced in cold merger periods also end up with a lower stock price. However, the results for the merger wave regression are mostly insignificant, which suggests that the bidder's long-run return depends on the last deal rather than on the quantity of merger deals conducted in the previous year. However, the result for the high-valuation control portfolio is significantly negative. This evidence partially suggests that mergers announced during waves have worse performance, on average, in the long-run than mergers announced at other times consistent with Rosen (2006) and Bouwman, Fuller and Nain (2006).

Panel C presents the results for the market momentum variables also showed the reversal of the CAR. The coefficient of the increase in the stock index over the twelve months prior to an announcement was negative and significant for the high-valuation period portfolios $(-0.25$, $t=-2.91)$. For the total sample portfolio, the post-announcement and total window results also experienced a long-run reversal $(-0.12, t=-1.33)$, which was lower than in the case of the highvaluation period portfolio. In general, both results show that an acquisition announced during a high-valuation period is inferior, on average, in the long-run to acquisitions in other periods. This result holds even when the positive short-run reaction to the announcement of these mergers, i.e. the total window returns, is included.

Further, the regression results for the BHAR on bidder-specific merger momentum were examined in Panel D. The results indicate that we cannot conclude that firm-level momentum is reversed in the long-run as there is no strong evidence of reversal for the firm-specific momentum variables.

As in the short-run analysis, the trailing twelve-month BHARs on the bidder's stock was 
used to proxy the bidder-specific stock momentum pattern. This is the BHAR on the bidder's stock in the twelve months ending three days before an announcement. Strong evidence was found for the effect of bidder-specific stock momentum on the bidder's long-run performance, as the coefficient of this control variable was negative and significant in all portfolios. This evidence supports the hypothesis of investor sentiment, as investors are getting overenthusiastic due to the stock price run-up but penalize it with time when understanding that the merger was not a good deal indeed.

Furthermore, the high-valuation post- announcement period control portfolio exhibits the most significant negative sign. This evidence suggests that managers of bidding firms make worse acquisition decisions when their firm is doing better in a high valuation period, probably due to the overvaluation effect suggested by Jensen (2004). ${ }^{20}$ On the other hand, acquisitions initiated in low-valuation periods generate insignificant results.

In Panel $\mathrm{F}$, we examine the results for the long-run regressions on the other control variables. Similar to the findings of the short-run analysis, these results are mostly consistent with previous research. For the private target acquisitions, insignificant coefficients are obtained for all the holding portfolios $(0.012$ with $t=0.34),{ }^{21}$ although the magnitude is lower than for the short-run analysis. For acquisitions involving subsidiaries, we find significant positive coefficients $(0.17$ with $t=2.12)$ and this suggests that over a period of time, the bidder's performance gradually gets better. These results, however, strengthen the fact that bidders involved in non-public target acquisitions yield better returns compared to public acquisitions.

For the stock financing and other financing control variables, similar results were found to those obtained from the short-run analysis. Bidders that acquired with stock did consistently worse in the long-run, as is indicated by the negative coefficient $(-0.053$ with $t=-0.75)$. On the other hand, for acquirers that financed the transaction solely with cash or made a mixed offer the coefficients are significantly positive $(0.012$ with $\mathrm{t}=1.84)$.

\footnotetext{
${ }^{20}$ Jensen (2004) suggested that agency costs increase surprisingly during overvaluation periods, and that one of the major reasons for this is the need to meet analysts' forecasts. Managers who fail to meet the target set by the analyst will face the problem of disappointing the market. Hence, they will initiate acquisitions even where they are not profitable in the long-run, but can boost their stock temporally.

${ }^{21}$ All the results we discuss here are for all-sample post announcement period regressions.
} 
Interestingly, we find a very significant size effect in the long-run study. As noted earlier, the bidder to target size ratio could be an important indicator of the bidder's long-run performance. It was found that as the target size in relation to the bidder increases, the bidders show a positive long-run performance in all the holding portfolios. To sum up, when investigating merger momentum in the long-run, the results are consistent with the hypothesis that momentum is caused by over-optimism, as positive short-run returns vanish with time and there is a strong tendency for long-run reversal over time.

\section{[Insert Table 4 About Here]}

\section{Conclusion}

The aim of this study is to examine the merger momentum effect, i.e. the interaction between broad market conditions and the market's response to a merger announcement. To explain the source of merger momentum, the interaction between bidders' performance and previous recent deals was examined. Firstly, the market's reaction to merger announcements was decomposed into several factors. It was found that merger outcome not only depends on the bidders, but also correlates with broader market conditions and stock market price levels, and most importantly, it depends on how other recent deals have been received by the market. Secondly, evidence is provided that high market valuations do affect the quality of merger deals, and stimulate the short-run returns, but lead to significant long-run reversals. In particular, it was found that merger momentum is rather stronger when the market tends to be overvalued compared to other periods.

Three hypotheses have been put forward to explain the source of merger momentum (the hubris hypothesis, the neoclassical hypothesis, and the investor sentiment hypothesis). The short-run results of this study revealed that the two latter hypotheses provide reasonable explanations as we find positive and significant results in the short-run in contrast to the predictions of hubris hypothesis. However, the long-run results support the theory that investor sentiment is the driving force behind the market's reaction to merger announcements. If investors' reactions to merger announcements are based on the rational expectation of combined synergy then they will react positively to merger announcements with no long-run 
drift. If neoclassical theory, which states that industry or economic shocks create synergy, holds then more positive market reaction should be seen during high valuation periods as these contain many common shocks. However, there should be no reason for reversals in the longrun. On the other hand, when the majority of investors are infected by optimistic beliefs, the short-run positive abnormal returns caused by a merger announcement are reversed in the long-run as this optimism is eventually replaced by reality. When considering the driving force of investor optimism it is more likely that this optimism increases during high-valuation periods. To sum up, it seems that mergers are subject to more behavioural biases when market valuation is high and these form merger waves; deals within merger waves tend to be correlated with each other and co-move in the same direction. 


\section{References}

Andrade, G., Mitchell, M. and Stafford E. (2001) New evidence and perspectives on mergers, Journal of Economic Perspectives 15, 103-120.

Asquith, P., Bruner, R. and Mullins, D. (1983) The gains to bidding firms from merger, Journal of Financial Economics 11, 121-140.

Barber, R. and Lyon, J. (1997) Detecting long-run abnormal stock returns: the empirical power and specifications of test statistics. Journal of Financial Economics 43, 341-372.

Berger, P. and Ofek, E. (1995) Diversification's effect on firm value, Journal of Financial Economics 37, 39-65.

Bouwman, C., Fuller, K. and Nain. A. (2006) Market valuation and acquisition quality: Empirical evidence, Review of Financial Studies, Forthcoming.

Bradley, M., Anand, D., Desai, S. and Kim, H. E. (1988) Synergistic gains from corporate acquisitions and their division between the stockholders of target and acquiring firms, Journal of Financial Economics 21, 3-40.

Brown, S., Warner, J. (1985) Using daily stock returns: The case of event studies, Journal of Financial Economics, 14, 3-31.

Brown,S. and Warner, J. (1980) Measuring security price performance, Journal of Financial Economic 8, 205-258.

Dong, M., Hirshleifer,D., Richardson, S. and Teoh, S. H. (2006) Does Investor Misvaluation Drive the Takeover Market Journal of Finance 61, 725-762.

Doukas, J. and Petmezas, D. (2007) Acquisitions, overconfident managers and self-attribution bias. European Financial Management, Forthcoming

Faccio, M. and Masulis, R. W. (2005) The Choice of Payment Method in European Mergers and Acquisitions, Journal of Finance 60, 1345-1388.

Fama, E. and French, K. (1992) The cross-section of expected stock returns, Journal of Finance 47, 427-465.

Fuller, K., Netter, J. and Stegemoller, M. (2002) What Do Returns to Acquiring Firms Tell Us? Evidence from Firms that Make Many Acquisitions, Journal of Finance 57, 1763-1793.

Helwege, J. and Liang, N. (1996) Initial Public Offerings in Hot and Cold Markets. Board of Governors of the Federal Reserve System, Finance and Economics, Discussion Series: $96 / 34$

Holmstrom, B. and Kaplan, S. N. (2001) Corporate governance and merger activity in the United States: Making sense of the 1980s and 1990s. Journal of Economic Perspectives 15, 121-144.

Jensen M. C. and Ruback, R. S. (1983) The market for corporate control: the scientific evidence, Journal of Financial Economics 11, 5-50.

Jensen, M. C. (2004) The agency cost of overvalued equity and the current state of corporate finance , European Financial Management 10 (4), 549-565.

Jovanovic, B. and Rousseau, P. (2002) The q-theory of mergers. The American Economic Review, 92 (2), 198-204.

Lang, L. H. P. and Stulz, R. (1994) Tobin's q, corporate diversification, and firm performance, Journal of Political Economy 102, 1248-1280.

Lang, L. H. P., Stulz, R. M and Walking, R.A. (1989) Managerial performance, Tobin's q, and the gains from successful tender offers. Journal of Financial Economics 24, 137-154.

Loderer, C. and Kenneth, M. (1992) Post-acquisition performance of acquiring firms, Financial Management 21(3), 69-79.

Loughran, T. and Vijh, A. M. (1997) Do long-term shareholders benefit from corporate acquisitions, Journal of Finance 52, 1765-1790.

Mitchell, M. L., and Mulherin, H. (1996) The impact of industry shocks on takeover and restructuring activity, Journal of Financial Economics 41, 193-229.

Moeller, S. B., Schlingemann, F. P. and Stulz, R. M. (2005) Wealth destruction on a massive scale? A study of acquiring- firm returns in the recent merger wave, Journal of Finance 60, 757-782.

Morck, R., Shleifer, A. and Vishny, R. W. (1990) Do managerial objectives drive bad acquisitions? Journal of Finance 45, 31-48. 
Rau, P. R. and Vermaelen, T. (1998) Glamour, value and the post-acquisition performance of acquiring firms, Journal of Financial Economics, 49, 223-253.

Rhodes-Kropf, M. and Viswanathan, S. (2004) Market valuation and merger waves, Journal of Finance, 59 (6), 2685-2718.

Roll, R. (1986) The hubris hypothesis of corporate takeovers, Journal of Business 59, 197-216.

Rosen, R. J. (2006) Merger momentum and investor sentiment: the stock market reaction to merger announcements. Journal of Business, Forthcoming

Servaes, H. (1991) Tobin's Q and the gains from takeovers, Journal of Finance 46, 409-419

Servaes, H. (1996) The Value of diversification during the conglomerate merger wave Journal of Finance 51, 1201-1225.

Shleifer, A.and Vishny, R. W. (2004) Stock market driven acquisitions, Journal of Financial Economics, Elsevier, 70 (3), 295-311.

Travlos, G. N. (1987) Corporate takeover bids, methods of payment, and bidding firms' stock returns, Journal of Finance 42, 943-963. 
Table 1. Descriptive Statistics for M\&A Sample

This table presents descriptive statistics of 1957 completed acquisitions made by UK publicly traded firms during the 1985 to 2002 period. $\mathrm{N}$ is the number of deals per year. The second column reports the number of acquisitions and the columns 3 to 7 the mean and median market value of acquirers and the mean and median transaction value of the acquisition. The last three columns list the percentage of acquisitions by method of payment. Acquirers are publicly traded firms listed on the London Stock Exchange (LSE). Targets are public, private and subsidiary UK firms. Transaction values reported in millions of pounds. Cash deals are those that involved $100 \%$ cash payment and stock deals are those that involved $100 \%$ stock payment. Mixed payment acquisitions consist of all acquisitions in which the payment method neither is pure cash nor pure stock and/or convertibles, of the choice offered to target owners and methods classified as "other" by SDC. We define a merger as an acquisition of equity where one firm purchases at least $50 \%$ of another and after the purchase; the bidder owns at least $90 \%$ of the target. We also require that the target be at least $5 \%$ of the bidder's size.

\begin{tabular}{|c|c|c|c|c|c|c|c|c|c|}
\hline Year & $\mathbf{N}$ & $\begin{array}{c}\text { Total Deal } \\
\text { Value } \\
\text { ( } £ \text { mln) }\end{array}$ & $\begin{array}{c}\text { Mean } \\
\text { Market } \\
\text { Equity } \\
\text { (£ mln) }\end{array}$ & $\begin{array}{c}\text { Median } \\
\text { Market } \\
\text { Equity } \\
\text { (£ mln) }\end{array}$ & $\begin{array}{c}\text { Mean } \\
\text { Transaction } \\
\text { Value } \\
(£ \text { mln })\end{array}$ & $\begin{array}{c}\text { Median } \\
\text { Transaction } \\
\text { Value } \\
(£ \text { mln })\end{array}$ & $\begin{array}{c}\text { Cash } \\
\text { offer } \\
(\%)\end{array}$ & $\begin{array}{c}\text { Stock } \\
\text { offer } \\
(\%)\end{array}$ & $\begin{array}{c}\text { Mixed } \\
\text { offer } \\
(\%)\end{array}$ \\
\hline (1) & (2) & (3) & (4) & (5) & (6) & (7) & (8) & (9) & (10) \\
\hline 1985 & 11 & 402.51 & 159.53 & 67.78 & 36.59 & 28.23 & 58.33 & 33.33 & 8.34 \\
\hline 1987 & 69 & 1383.56 & 109.24 & 38.93 & 20.05 & 7.5 & 72.46 & 8.7 & 18.84 \\
\hline 1988 & 172 & 3564.14 & 76.64 & 30.1 & 20.72 & 4.57 & 58.14 & 3.49 & 38.37 \\
\hline 1989 & 143 & 3186.6 & 86.68 & 42.64 & 22.28 & 6 & 51.75 & 6.29 & 41.96 \\
\hline 1990 & 99 & 874.68 & 47.27 & 25.5 & 8.84 & 4.5 & 62.63 & 3.03 & 34.34 \\
\hline 1994 & 116 & 1656.01 & 94.53 & 48.31 & 14.28 & 6.8 & 49.14 & 2.59 & 48.27 \\
\hline 1995 & 108 & 1609.79 & 87.76 & 42.66 & 14.91 & 6.19 & 44.44 & 9.26 & 46.3 \\
\hline 1996 & 115 & 3061.32 & 100.75 & 38.28 & 26.62 & 7.1 & 43.48 & 0 & 56.52 \\
\hline 1997 & 173 & 2851.23 & 96.28 & 44.95 & 16.48 & 7 & 47.4 & 5.2 & 47.4 \\
\hline 1998 & 163 & 2593.07 & 83.11 & 37.86 & 15.91 & 7.5 & 65.64 & 3.68 & 30.68 \\
\hline 1999 & 149 & 5082.85 & 120.11 & 53.33 & 34.11 & 11 & 50.34 & 4.03 & 45.63 \\
\hline 2000 & 178 & 5855.34 & 139.93 & 65.37 & 32.9 & 10.8 & 44.94 & 3.37 & 51.69 \\
\hline 2001 & 124 & 2334.43 & 118.03 & 38.91 & 18.8 & 6.9 & 25.81 & 4.84 & 69.35 \\
\hline
\end{tabular}




\section{Table 2. Summary Statistics}

This table presents summary statistics for the sample of 1957 completed public, private and subsidiary acquisitions made by UK publicly traded firms during the 1985 to 2002 period. Trailing 12-month average cumulative announcement return (CAAR) is the average CAAR for all sample mergers in the 12 months ending 3 days before an announcement. Trailing 12-month number of mergers is the number of sample mergers in the 12 months prior to an announcement. Trailing 12month FTSE All Share index return is the return on the value-weighted FTSE All Share index in the year ending three days before a merger announcement. CAAR for the last announcement by the firm is for the most recent merger where the target is at least $5 \%$ the size of the bidder as long as the merger was announced in the three years prior to the current announcement. Stock financing is the percent of mergers that are entirely financed by stock. Other financing is the percent of merger that have some non-stock financing. Target is public, private, and subsidiary refer to the percent of mergers with that type of targets. Acquirer's market value is defined as the acquirer's market value one month before the acquisition announcement date. Acquirer's book-to-market ratio is calculated one month prior to the acquisition announcement date and is the product of the net book value divided by the Market Value. The relative size of the target is defined as the deal value divided by the market value of the acquirer. The Acquirer Market Value (MV) is the monthly share price multiplied by the number of ordinary shares (as reported in Datastream) the month before the announcement date. Diversifying merger is the percent of mergers where the target and bidding firm are in different industries. An acquisition is defined as diversified when the acquirer's two-digit SIC code is different from that of the target company.

\begin{tabular}{|c|c|c|c|}
\hline Variables & Mean & Median & Std. dev \\
\hline Trailing 12-Month Average CAR & $1.2 \%$ & $1.23 \%$ & $0.9 \%$ \\
\hline Trailing 12-Month number of mergers & 128 & 127 & 41 \\
\hline Trailing 12-Month return on FTSE All-Share Index & $13.9 \%$ & $11.3 \%$ & $22.3 \%$ \\
\hline $\begin{array}{l}\text { Dummy }=1 \text { if this is the First Announcement by the } \\
\text { Bidder in the Prior } 3 \text { Years }\end{array}$ & $59.4 \%$ & 1 & $49.1 \%$ \\
\hline $\begin{array}{l}\text { Number of Mergers by the Bidder Over a 3-Year } \\
\text { Period Prior to the Announcement }\end{array}$ & 0.71 & 0 & 1.11 \\
\hline Stock Financing & $6.9 \%$ & 0 & $28.5 \%$ \\
\hline Other Financing & $93.1 \%$ & 1 & $38.9 \%$ \\
\hline Target is Public Firm & $2.2 \%$ & 0 & $14.7 \%$ \\
\hline Target is Private Firm & $57.2 \%$ & 1 & $49.5 \%$ \\
\hline Target is Subsidiary & $40.6 \%$ & 0 & $49.1 \%$ \\
\hline Acquirer MV ( $£ \mathrm{mln})$ & 105.8 & 40.2 & 186.2 \\
\hline Acquirer Book to Market & 0.47 & 0.42 & 0.47 \\
\hline Log of Acquirer MV & 1.63 & 1.6 & 0.55 \\
\hline Relative Size of Target to Bidder & $21.1 \%$ & $15.6 \%$ & $24.1 \%$ \\
\hline Diversifying Mergers & $40.3 \%$ & 0 & $49.2 \%$ \\
\hline
\end{tabular}




\section{Table 3. Regression Results for the CAAR}

This table presents the Cumulative Abnormal Returns (CAARs) of acquirers acquiring public, private and subsidiary targets over the 1985 and 2002 period. The dependent variable is the cumulative average abnormal announcement return (CAAR). CAARs are calculated for the five days $[-2,+2]$ around the announcement day (day 0 ) of a takeover. Abnormal Returns are estimated using a modified market-adjusted model: $\quad A R_{i t}=R_{i t}-R_{u}$

where $R_{i t}$ is the Return on firm i and $R_{m t}$ is the Value Weighed Market Index Return (FT-All Share). Trailing 12-month average cumulative abnormal announcement return (CAAR) is the average CAR for all sample mergers in the 12 months ending 3 days before an announcement. Trailing 12-month number of mergers is the number of sample mergers in the 12 months prior to an announcement. Trailing 12 -month FTSE All Share index return is the return on the value-weighted FTSE All Share index in the year ending three days before a merger announcement. CAAR for the last announcement by the firm is for the most recent merger where the target is at least $5 \%$ the size of the bidder as long as the merger was announced in the three years prior to the current announcement. The first merger dummy is one if the firm has made an acquisition in the three years prior to the announcement and zero otherwise. The buy and hold return (BHAR) on bidder's stock is the return in the 12 months ending three days before an announcement. Stock financing is the percent of mergers that are entirely financed by stock. Other financing is the percent of mergers that have some nonstick financing. Target is public, private, and subsidiary refer to the percent of mergers with that type of target. The relative size of the target is defined as the deal value divided by the market value of the acquirer. The Acquirer Market Value (MV) is the monthly share price multiplied by the number of ordinary shares (as reported in Datastream) the month before the announcement date. Bidder book-to-market ratio is calculated one month prior to the acquisition announcement date and is the product of the net book value divided by the Market Value. An acquisition is defined as diversified when the acquirer's two-digit SIC code is different from that of the target company. Results are further partitioned by valuation period to acquisitions undertaken during high, low and neutral valuation periods respectively. a, b, indicate statistical significance at the $1 \%$ and $5 \%$ levels respectively.

\begin{tabular}{|c|c|c|c|c|c|c|c|c|c|c|c|c|}
\hline \multicolumn{13}{|c|}{ Dependent Variable: CAAR } \\
\hline & \multicolumn{2}{|c|}{$\begin{array}{c}\text { Full sample } \\
\text { (1) } \\
\end{array}$} & \multicolumn{2}{|c|}{$\begin{array}{c}\text { Early time period } \\
1985-1989 \\
(2)\end{array}$} & \multicolumn{2}{|c|}{$\begin{array}{c}\text { Later time period } \\
1990-2002 \\
(3)\end{array}$} & \multicolumn{2}{|c|}{$\begin{array}{l}\text { High Valuation Period } \\
\text { (4) }\end{array}$} & \multicolumn{2}{|c|}{$\begin{array}{c}\text { Neutral Valuation } \\
\text { Period } \\
(5)\end{array}$} & \multicolumn{2}{|c|}{$\begin{array}{l}\text { Low Valuation Period } \\
\text { (6) }\end{array}$} \\
\hline & Coef. & t-value & Coef. & t-value & Coef. & t-value & Coef. & t-value & Coef. & t-value & Coef. & $\mathrm{t}$-value \\
\hline \multicolumn{13}{|c|}{ Panel A: Merger Momentum } \\
\hline $\begin{array}{l}\text { Trailing 12-Month } \\
\text { CAAR }\end{array}$ & 0.20 & $(2.73)^{\mathrm{a}}$ & -0.34 & $(-1.23)$ & 0.27 & $(2.25)^{a}$ & 0.41 & $(2.82)^{a}$ & 0.21 & $(0.75)$ & 0.12 & (1.18) \\
\hline $\begin{array}{c}\text { Trailing 12-Month } \\
\text { Number of } \\
\text { Mergers } / 1000 \\
\end{array}$ & -0.008 & $(-1.62)$ & -0.097 & $(-1.98)^{b}$ & -0.003 & $(-1.56)$ & -0.001 & $(-2.35)^{\mathrm{a}}$ & -0.017 & $(-1.95)^{\mathrm{b}}$ & -0.055 & $(-0.83)$ \\
\hline \multicolumn{13}{|c|}{ 1Panel B: Market Momentum } \\
\hline $\begin{array}{c}\text { Trailing 12-Month } \\
\text { Return on FTSE Index }\end{array}$ & 0.003 & $(0.67)$ & 0.011 & (1.05) & 0.027 & $(1.96)^{b}$ & 0.035 & $(3.72)^{a}$ & 0.013 & (1.51) & -0.039 & $(-2.38)^{a}$ \\
\hline \multicolumn{13}{|c|}{ Panel C: Bidder-Specific Merger Momentum } \\
\hline $\begin{array}{l}\text { CAAR on Bidder's Last } \\
\text { Announcement }\end{array}$ & 0.052 & $(1.52)$ & 0.037 & $(1.23)$ & 0.067 & $(1.88)^{b}$ & 0.045 & $(2.73)^{\mathrm{a}}$ & 0.056 & $(1.29)$ & 0.027 & $(0.82)$ \\
\hline First Merger Dummy & 0.002 & $(0.41)$ & -0.003 & $(0.43)$ & -0.005 & $(-0.81)$ & 0.008 & $(3.07)^{\mathrm{a}}$ & 0.005 & $(1.98)^{\mathrm{b}}$ & -0.048 & $(-1.02)$ \\
\hline $\begin{array}{l}\text { Number of Mergers by } \\
\text { Firm in Last } 3 \text { Years }\end{array}$ & 0.001 & $(0.65)$ & 0.001 & $(1.53)$ & 0.001 & $(0.61)$ & 0.003 & $(1.24)$ & 0.001 & $(1.33)$ & -0.004 & $(-0.91)$ \\
\hline \multicolumn{13}{|c|}{ Panel D: Bidder-Specific Stock Momentum } \\
\hline $\begin{array}{c}\text { Trailing 12-Month } \\
\text { BHAR on Bidder's } \\
\text { Stock }\end{array}$ & -0.005 & $(-1.98)^{b}$ & 0.009 & $(1.56)$ & -0.008 & $(-2.12)^{b}$ & -0.006 & $(-2.34)^{b}$ & -0.006 & $(-1.20)$ & -0.015 & $(-0.37)$ \\
\hline \multicolumn{13}{|c|}{ Panel E: Control Variables } \\
\hline Private & 0.008 & $(1.95)^{\mathrm{b}}$ & 0.005 & (1.43) & 0.009 & $(2.09)^{b}$ & 0.05 & $(2.08)^{\mathrm{b}}$ & 0.012 & $(1.82)^{\mathrm{b}}$ & 0.004 & (1.39) \\
\hline Subsidiary & 0.011 & $(1.72)^{b}$ & 0.003 & $(0.76)$ & 0.012 & $(1.41)$ & 0.042 & $(1.72)^{b}$ & 0.012 & $(1.44)$ & 0.025 & $(0.72)$ \\
\hline Stock Financing & -0.18 & $(-1.55)$ & -0.07 & $(-0.56)$ & -0.09 & $(-0.85)$ & -0.06 & $(-1.45)$ & -0.21 & $(-0.89)$ & -0.09 & $(-1.92)^{b}$ \\
\hline Other Financing & 0.15 & $(2.32)^{b}$ & 0.08 & $(2.79)^{a}$ & 0.10 & $(1.33)$ & 0.24 & $(2.12)^{b}$ & 0.16 & $(2.66)^{a}$ & 0.03 & $(1.13)$ \\
\hline Log of total assets & -0.023 & $(-0.86)$ & -0.006 & $(-1.45)$ & 0.001 & $(0.92)$ & 0.004 & $(1.98)^{b}$ & 0.012 & $(0.69)$ & -0.037 & $(-1.74)^{b}$ \\
\hline $\begin{array}{c}\text { Relative Size of Target } \\
\text { to Bidder }\end{array}$ & 0.006 & $(1.73)^{b}$ & 0.013 & $(1.47)$ & 0.005 & $(1.97)^{b}$ & 0.02 & $(4.66)^{\mathrm{a}}$ & 0.031 & $(2.05)^{\mathrm{b}}$ & -0.074 & $(-0.38)$ \\
\hline Bidder Book-to-Market & 0.005 & $(0.87)$ & 0.007 & $(0.75)$ & 0.004 & $(0.56)$ & 0.002 & $(2.63)^{a}$ & 0.005 & $(3.23)^{a}$ & 0.012 & $(1.17)$ \\
\hline Diversifying Mergers & 0.002 & $(2.55)^{a}$ & 0.003 & $(3.67)^{\mathrm{a}}$ & -0.001 & $(-1.34)$ & 0.001 & $(1.22)$ & 0.007 & $(1.55)$ & -0.051 & $(-1.01)$ \\
\hline Observations & \multicolumn{2}{|c|}{1957} & \multicolumn{2}{|c|}{421} & & & \multicolumn{2}{|c|}{810} & \multicolumn{2}{|c|}{629} & \multicolumn{2}{|c|}{518} \\
\hline
\end{tabular}




\section{Table 4. Regression Results for the BHAR}

The BHAR is defined as $\prod_{t=1}^{T}\left(1+R_{t}\right)-\prod_{t=1}^{T}\left(1+R_{\text {index,t }}\right)$ (where Rt is the return on the bidding firm's stock and Rindex,t is the return on the FTSE All Share value-weighted

index. We include acquisitions with at least one year of observations after the announcement. The post-announcement window runs from three days after an announcement to three years after the announcement. The total window runs from two days before an announcement to three years after the announcement. Trailing 12-month average cumulative abnormal announcement return (CAAR) is the average CAR for all sample mergers in the 12 months ending 3 days before an announcement. Trailing 12-month number of mergers is the number of sample mergers in the 12 months prior to an announcement. Trailing 12-month FTSE All Share index return is the return on the value weighted FTSE All Share index in the year ending three days before a merger announcement. CAAR for the last announcement by the firm is for the most recent merger where the target is at least $5 \%$ the size of the bidder as long as the merger was announced in the three years prior to the current announcement. The first merger dummy is one if the firm has made an acquisition in the three years prio to the announcement and zero otherwise. The buy-and-hold return (BHAR) on bidder's stock is the return in the 12 months ending three days before an announcement. Stock financing is the percent of mergers that are entirely financed by stock. Other financing is the percent of mergers that have some non-stock financing. Target is public, private, and subsidiary refer to the percent of mergers with that type of target. The ratio of target-to-bidder size is the ratio of target equity to bidder equity. Bidder book-to-market is the book-tomarket equity ratio and measured at the end of the year prior to the merger announcement Diversifying merger is the percent of mergers where the target and the bidding firm are in different industries. Industry dummies are included in the regressions but not shown in the table. The data cover mergers announced between 1985 and 2002 . There are 1957 observations. Results are further partitioned by valuation period to acquisitions undertaken during high, low and neutral valuation periods respectively. a, b, indicate statistical significance at the $1 \%$ and $5 \%$ levels respectively.

\begin{tabular}{|c|c|c|c|c|c|c|c|c|}
\hline \multicolumn{9}{|c|}{ Dependent Variable: BHAR } \\
\hline & \multicolumn{2}{|c|}{$\begin{array}{l}\text { Post announcement return } \\
\text { (1) }\end{array}$} & \multicolumn{2}{|c|}{$\begin{array}{l}\text { Total window returns } \\
\text { (2) }\end{array}$} & \multicolumn{2}{|c|}{$\begin{array}{l}\text { High valuation period post } \\
\text { announcement returns } \\
\text { (3) }\end{array}$} & \multicolumn{2}{|c|}{$\begin{array}{l}\text { High valuation period total } \\
\text { window returns } \\
(4)\end{array}$} \\
\hline & Coef. & t-value & Coef. & t-value & Coef. & t-value & Coef. & t-value \\
\hline Panel A: Bidder's CAAR & -1.03 & $(-2.76)^{\mathrm{a}}$ & & & -1.08 & $(-3.35)^{a}$ & & \\
\hline \multicolumn{9}{|c|}{ Panel B: Merger Momentum } \\
\hline Trailing 12-Month CAAR & -9.72 & $(-5.61)^{a}$ & -10.33 & $(-1.95)^{b}$ & -11.23 & $(-4.52)^{a}$ & -8.66 & $(-2.55)^{a}$ \\
\hline Trailing 12-Month Number of Mergers/1000 & 0.33 & $(0.65)$ & 0.12 & $(0.78)$ & 0.27 & (2.32) b & 0.11 & $(1.86) \mathrm{b}$ \\
\hline \multicolumn{9}{|c|}{ Panel C: Market Momentum } \\
\hline Trailing 12-month return on FTSE Index & -0.12 & $(-1.33)$ & -0.34 & $(-1.67)^{b}$ & -0.25 & $(-2.91)^{a}$ & -0.38 & $(-2.45)^{a}$ \\
\hline \multicolumn{9}{|c|}{ Panel D: Bidder-Specific Merger Momentum } \\
\hline CAAR on Bidder's Last Announcement & 0.15 & $(0.44)$ & 0.21 & $(0.87)$ & 0.35 & $(1.75)^{b}$ & 0.28 & $(2.12)^{b}$ \\
\hline First Merger Dummy & 0.09 & $(1.88)^{b}$ & 0.11 & $(1.67)^{b}$ & 0.07 & $(2.54)^{a}$ & 0.12 & $(3.89)^{a}$ \\
\hline Number of Mergers by Firm in Last 3 Years & 0.028 & $(1.76)^{b}$ & 0.012 & $(1.98)^{b}$ & 0.016 & $(3.42)^{a}$ & 0.022 & $(2.12)^{b}$ \\
\hline \multicolumn{9}{|c|}{ Panel E: Bidder-Specific Stock Momentum } \\
\hline Trailing 12-Month BHAR on Bidder's Stock & -0.075 & $(-3.26)^{a}$ & -0.062 & $(-2.67)^{a}$ & -0.11 & $(-4.87)^{a}$ & -0.092 & $(-2.55)^{a}$ \\
\hline \multicolumn{9}{|c|}{ Panel F: Control Variables } \\
\hline $\begin{array}{l}\text { Private Target } \\
\text { Subsidiary }\end{array}$ & $\begin{array}{c}0.012 \\
0.17\end{array}$ & $\begin{array}{l}(0.34) \\
(2.12) b\end{array}$ & $\begin{array}{l}0.037 \\
0.092\end{array}$ & $\begin{array}{l}(0.82) \\
(1.32)\end{array}$ & $\begin{array}{c}0.006 \\
0.12\end{array}$ & $\begin{array}{l}(0.95) \\
(2.01)\end{array}$ & $\begin{array}{l}0.021 \\
0.092\end{array}$ & $\begin{array}{l}(1.54){ }^{a} \\
(2.33)^{a}\end{array}$ \\
\hline $\begin{array}{l}\text { Stock Financing } \\
\text { Other Financing }\end{array}$ & $\begin{array}{r}-0.053 \\
0.012\end{array}$ & $\begin{array}{l}(-0.75) \\
(1.84)\end{array}$ & $\begin{array}{c}-0.077 \\
0.016\end{array}$ & $\begin{array}{l}(-0.38) \\
(2.55)\end{array}$ & $\begin{array}{c}-0.065 \\
0.011\end{array}$ & $\begin{array}{l}(-1.45) \\
(2.88)^{a}\end{array}$ & $\begin{array}{l}-0.042 \\
0.016\end{array}$ & $(-1.28) b$ \\
\hline Log of total assets & 0.031 & $(3.75)^{a}$ & 0.023 & $(1.42)$ & 0.043 & $(1.66)^{b}$ & 0.035 & $(2.89)^{a}$ \\
\hline Relative Size of Target to Bidder & 0.27 & $(4.45)^{\mathrm{a}}$ & 0.18 & $(2.35)^{a}$ & 0.11 & $(2.29)^{b}$ & 0.17 & $(1.97)^{b}$ \\
\hline Bidder Book-to-Market & 0.057 & $(1.19)$ & 0.053 & $(2.69)^{\mathrm{a}}$ & 0.052 & $(2.05)^{b}$ & 0.046 & $(0.77)$ \\
\hline Diversifying Mergers & 0.17 & $(3.87)^{a}$ & 0.19 & $(2.76)^{a}$ & 0.21 & $(1.65)^{b}$ & 0.26 & $(1.53)$ \\
\hline
\end{tabular}




\begin{tabular}{|c|c|c|c|c|c|c|c|c|}
\hline \multicolumn{9}{|c|}{ Dependent Variable: BHAR } \\
\hline & \multicolumn{2}{|c|}{$\begin{array}{l}\text { Neutral valuation period post } \\
\text { announcement returns } \\
(5)\end{array}$} & \multicolumn{2}{|c|}{$\begin{array}{l}\text { Neutral valuation period total } \\
\text { window returns } \\
(6)\end{array}$} & \multicolumn{2}{|c|}{$\begin{array}{l}\text { Low valuation period post } \\
\text { announcement returns } \\
\text { (7) }\end{array}$} & \multicolumn{2}{|c|}{$\begin{array}{l}\text { Low valuation period tota } \\
\text { window returns } \\
(8)\end{array}$} \\
\hline & Coef. & t-value & Coef. & t-value & Coef. & t-value & Coef. & t-value \\
\hline Panel A: Bidder's CAAR & -1.05 & $(-2.55)^{\mathrm{a}}$ & & & -1.01 & $(-1.85)^{b}$ & & \\
\hline \multicolumn{9}{|c|}{ Panel B: Merger Momentum } \\
\hline Trailing 12-Month CAAR & -10.66 & $(-4.42)^{a}$ & -10.15 & $(-2.49)^{\mathrm{a}}$ & -9.79 & $(-1.16)$ & -8.03 & $(-1.97)^{b}$ \\
\hline Trailing 12-Month Number of Mergers/1000 & 0.29 & $(1.42)$ & 0.13 & $(1.89)^{b}$ & 0.18 & $(0.89)$ & 0.13 & $(1.35)$ \\
\hline \multicolumn{9}{|c|}{ Panel C: Market Momentum } \\
\hline Trailing 12-month return on FTSE Index & -0.19 & $(-0.97)$ & -0.27 & $(-2.88)^{a}$ & -0.08 & $(-1.24)$ & -0.14 & $(-1.69)^{b}$ \\
\hline \multicolumn{9}{|c|}{ Panel D: Bidder-Specific Merger Momentum } \\
\hline $\begin{array}{l}\text { CAAR on Bidder's Last Announcement } \\
\text { First Merger Dummy }\end{array}$ & $\begin{array}{l}0.26 \\
0.11\end{array}$ & $(1.53){ }^{a}$ & $\begin{array}{l}0.2 \\
0.09\end{array}$ & $(0.48)$ & $\begin{array}{l}0.19 \\
0.23\end{array}$ & $\begin{array}{l}(1.02) \\
(1.39)\end{array}$ & $\begin{array}{l}0.16 \\
0.19\end{array}$ & $(0.79) \mathrm{b}$ \\
\hline Number of Mergers by Firm in Last 3 Years & 0.012 & $(0.51)$ & 0.018 & $(1.82)^{b}$ & -0.033 & $(-1.50)$ & -0.03 & $(-1.29)$ \\
\hline \multicolumn{9}{|c|}{ Panel E: Bidder-Specific Stock Momentum } \\
\hline Trailing 12-Month BHAR on Bidder's Stock & -0.15 & $(-2.01)^{a}$ & -0.053 & $(-1.42)$ & 0.18 & $(1.57)$ & 0.14 & $(1.42)$ \\
\hline \multicolumn{9}{|c|}{ Panel F: Control Variables } \\
\hline Private Target & 0.012 & $(1.61)$ & 0.029 & $(1.22)$ & 0.024 & $(1.95)^{b}$ & 0.033 & (1.29) \\
\hline Subsidiary & 0.13 & $(1.51)$ & 0.19 & $(1.88)^{b}$ & 0.24 & $(2.18)^{b}$ & 0.16 & $(1.29)$ \\
\hline $\begin{array}{l}\text { Stock Financing } \\
\text { Other Financing }\end{array}$ & $\begin{array}{c}-0.041 \\
0.014\end{array}$ & $\begin{array}{l}(-1.26) \\
(2.25)\end{array}$ & $\begin{array}{c}-0.028 \\
0.017\end{array}$ & $\begin{array}{c}(-0.81) \\
(1.59)\end{array}$ & $\begin{array}{l}-0.022 \\
0.023\end{array}$ & $\begin{array}{l}(-1.08) \\
(1.69)\end{array}$ & $\begin{array}{c}-0.013 \\
0.029\end{array}$ & $\begin{array}{l}(-1.49) \\
(1.36)\end{array}$ \\
\hline Log of total assets & 0.038 & $(2.59)^{a}$ & 0.046 & $(1.57)$ & 0.12 & $(1.42)$ & 0.16 & $(1.98)^{b}$ \\
\hline Relative Size of Target to Bidder & 0.13 & $(2.29)^{b}$ & 0.17 & $(1.54)$ & 0.22 & $(1.36)$ & 0.15 & $(0.83)$ \\
\hline Bidder Book-to-Market & 0.043 & $(1.52)$ & 0.058 & $(1.79)^{b}$ & 0.084 & $(1.67)^{\mathrm{b}}$ & 0.061 & (1.28) \\
\hline Diversifying Mergers & 0.21 & $(1.98)^{b}$ & 0.24 & $(1.43)$ & 0.15 & $(0.95)$ & 0.18 & (0.92) \\
\hline
\end{tabular}

